\title{
ANALYSIS OF TOURISM POTENTIAL FOR CRETE ISLAND, GREECE
}

\section{A. MATZARAKIS ${ }^{1}$ \\ P. NASTOS ${ }^{2, *}$}

\author{
${ }^{1}$ Meteorological Institute, Albert-Ludwigs-University Freiburg, Germany \\ ${ }^{2}$ Laboratory of Climatology and Atmospheric Environment, \\ University of Athens \\ Panepistimiopolis GR 157 84, Athens, Greece
}

Received: 29/11/10

Accepted: 29/04/11 *to whom all correspondence should be addressed: e-mail: nastos@geol.uoa.gr

\begin{abstract}
To describe the tourism potential of an area, not only single meteorological parameters have to be taken into account, but also thermal sensation and people's thermal comfort. The latter can be estimated by the use of human energy balance models and the derived thermal indices, which comprise all relevant meteorological parameters like air temperature, air humidity, wind speed, and short and long wave radiation fluxes.

This paper makes an attempt to assess and analyze climatological parameters and the thermal comfort of Crete, its variations and trends for the period of time 1955-2001. In addition, a definition and quantification of the island's tourism potential is carried out.

Long term data from several stations are used from the existing climatic and synoptic network of Crete, including daily mean, maximum and minimum temperature, relative humidity, wind speed, and cloud cover over the whole island, in order to derive the daily Physiologically Equivalent Temperature (PET) and precipitation. In addition, possible trends of thermal comfort and precipitation on an annual and seasonal basis are analyzed.

Additionally, data of the 10-minutes climatology of the Climate Research Unit of the University of Norwich have been processed in order to create high resolution $(1 \mathrm{~km})$ mean monthly maps for climatological parameters such as air temperature, precipitation and Physiologically Equivalent Temperature.
\end{abstract}

KEYWORDS: Tourism potential, Physiologically Equivalent Temperature, Crete Island, Greece.

\section{INTRODUCTION}

Good climatic and bioclimatic conditions are crucial issues for competitiveness as climate is important for travel apart from costs, destination's natural resource base and attractions. Previous studies reveal that weather and climate are important factors for tourism decision making (Lin et al., 2006; Hamilton and Lau, 2005; de Freitas, 2003; Matzarakis et al., 2004; Didaskalou et al., 2007). Effective planning and management of a destination must take account of many factors that influence one's choice for a holiday to a specific region especially when the tourism product is coherent with the market segment of spa tourism (Didaskalou et al., 2007). The issue of seasonality in tourism flows has attracted the attention of tourism researchers for several decades (Amelung et al., 2007). Climate is an important part of a region's tourism resource base, but its role in determining the suitability of a region for tourism is often assumed to be self-evident and therefore to require no elaboration (de Freitas, 2003). Tourism in Greece has been growing significantly in certain areas such as Rodos, Crete, Corfu and Myconos. As the environmental impact is very extensive, the attempt to promote off-peak tourism to these or other destinations represents one way of reducing the pressure on the environment (Didaskalou and Nastos, 2003). Besides, health tourism have defined climate as an important factor that satisfies the needs of visitors of a spa/health resort (Didaskalou et al., 2004).

Crete, the biggest island of Greece, located in the eastern Mediterranean, is the most frequently visited Greek island by foreign visitors (about 2 million people) throughout the year. Tourism 
represents a major economic factor for Crete. Crete is the most important tourism destination in Greece. The number of overnight stays in Crete accounted for $26.7 \%$ of the overall Greek tourism market in 1999. In 2003 the number of arrivals in Crete reached 642.757 during the first six months, while the corresponding overnight stays reached 4.219.738. Most of the arrivals $(91.2 \%)$ were recorded from April to December, while only $8.8 \%$ of arrivals were recorded from January to March. So, in general, information on weather and climate/bioclimate are required for the quantification of the existing climate conditions on the one hand, and for the approximate calculation of possible implications and risks to human health resulting from extreme weather events on the other.

Because of its location in the eastern Mediterranean, the island of Crete has a mild climate with only slight variations. Also due to its geographic location, Crete is protected from the cold air masses of central and Western Europe in winter, and the high temperate air masses of North Africa in summer. Thus, the climate of Crete is temperate to maritime, except for most mountainous areas, where is mountainous. Crete has a very pleasant and healthy climate. The winters are mild, particularly in plain and coastal areas. In summer, air temperatures are rather pleasant due to the sea breeze and etesian winds (northerly winds from the Aegean Sea). In winter, the plains and coastlines areas of Crete, and particularly its eastern parts, are some of the warmest areas of the country. This is due to increased sunshine, scarce snowfalls and absence of frost (Meteorological Office, 1962).

This paper assesses and analyses the thermal sensation and general climate factors of Crete as well as their variations and trends for the period of time 1955-2001 in order to quantify the climate tourism potential of the island.

\section{METHODS}

In order to quantify the tourism climate conditions, long term data from seven stations (Heraklion, lerapetra, Kasteli, Rethymon, Sitia, Souda, and Tymbaki) of the existing climatic network of the Hellenic National Meteorological Service (HNMS) during the period 1955-2001 were used, including daily mean, maximum and minimum temperature, relative humidity, wind speed, and cloud cover. From these parameters, the daily Physiologically Equivalent Temperature (PET) was derived (VDI, 1998; Höppe, 1999; Matzarakis et al., 1999), in order to interpret the grade of the thermophysiologically stress (Table 1). PET is defined as the air temperature at which, in a typical indoor setting (without wind and solar radiation), the heat budget of the human body is balanced with the same core and skin temperature as under the complex outdoor conditions to be assessed.The results are presented in terms of 10-days intervals of the month (decas) in order to have a close relation to the periods of tourism periods.

Table 1. Ranges of the Physiologically Equivalent Temperature (PET) for different grades of thermal perception by human beings and physiological stress on human beings; internal heat production: 80

W, heat transfer resistance of the clothing: 0.9 clo (according to Matzarakis and Mayer, 1996)

\begin{tabular}{rcc}
\hline PET & Thermal Perception & Grade of Physiological Stress \\
\hline $4{ }^{\circ} \mathrm{C}$ & very cold & extreme cold stress \\
$8{ }^{\circ} \mathrm{C}$ & cold & strong cold stress \\
$13^{\circ} \mathrm{C}$ & cool & moderate cold stress \\
$18{ }^{\circ} \mathrm{C}$ & slightly cool & slight cold stress \\
$23^{\circ} \mathrm{C}$ & Comfortable & no thermal stress \\
$29^{\circ} \mathrm{C}$ & slightly warm & slight heat stress \\
$35{ }^{\circ} \mathrm{C}$ & - warm & moderate heat stress \\
$41{ }^{\circ} \mathrm{C}$ & hot & strong heat stress \\
\hline
\end{tabular}


The PET analysis was performed by the use of the radiation and bioclimate model, RayMan, which is well-suited to calculate radiation fluxes and human biometeorological indices (Matzarakis et al., $1999,2010)$ and was chosen for all our calculations of mean radiant temperature and PET. The RayMan model, developed according to the Guideline 3787 of the German Engineering Society (VDI, 1998) calculates the radiation flux in easy and complex environments on the basis of various parameters, such as air temperature, air humidity, degree of cloud cover, time of day and year, albedo of the surrounding surfaces and their solid-angle proportions (Matzarakis et al., 2010).

In addition, possible trends of thermal comfort on an annual and seasonal basis and precipitation were taken into account.

Also, geo-statistical methods have been applied and available climate data from the 10-minutes climatology (New et al. 1999, 2000) have been used to create high spatial resolution $(1 \mathrm{~km} \times 1 \mathrm{~km})$ maps of basic climatological parameters and the Physiologically Equivalent Temperature for the period of time 1961 - 1990.

\section{RESULTS}

The analysis of the tourism climate and tourism potential has been analysed through ombrothermic diagrams for the seven climate stations (Heraklion, lerapetra, Kasteli, Rethymon, Sitia, Souda, and Tymbaki) and their corresponding periods. Fig. 1 shows the ombrothermic diagram for Heraklion for the period $1955-2001$. With regards to air temperature variations in Crete, the data shows that in the first (cold and rainy) period from October to March, the coldest months are January and February. The mean minimum air temperature in these months varies between $7-9{ }^{\circ} \mathrm{C}$ in coastal areas, $4-6{ }^{\circ} \mathrm{C}$ in the mainland, and even lowers values in the highlands. In general, in this period, the eastern plain parts of Crete along with Dodecanese (the most south-eastern islands of Greece), are the warmest areas of Greece.

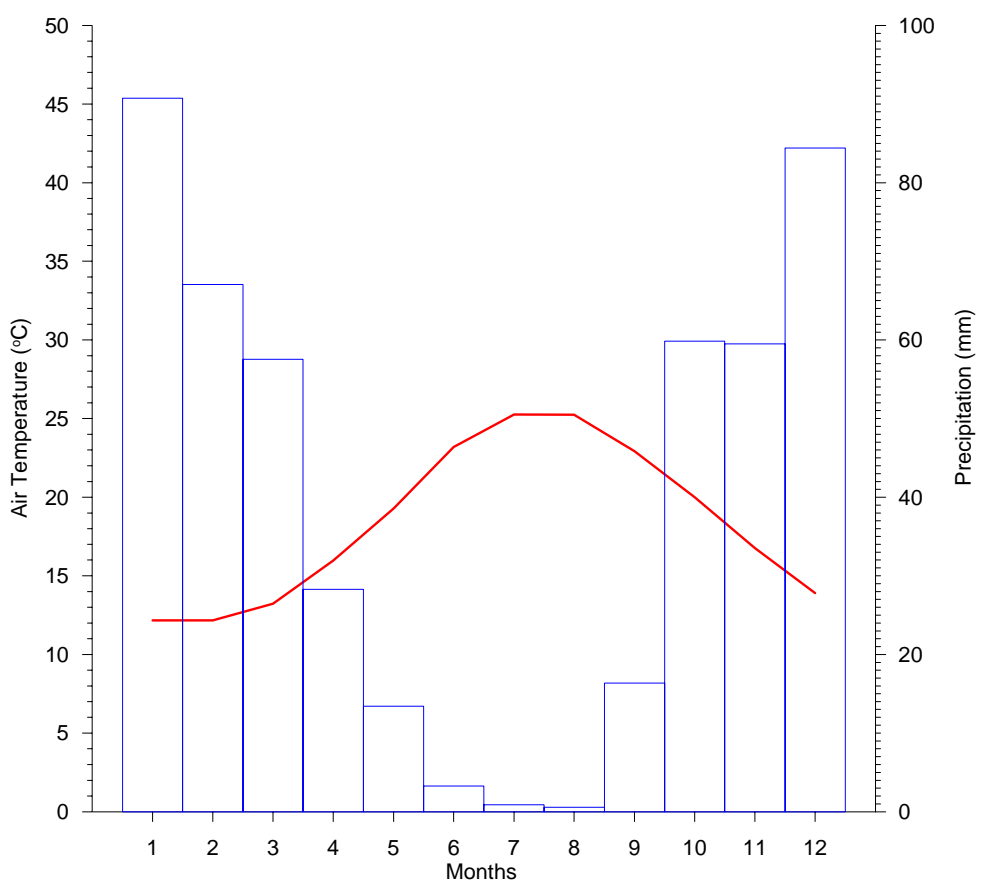

Figure 1. Ombrothermic diagram at Heraklio during the period 1955-2001; bars represent mean monthly precipitation totals $(\mathrm{mm})$ and red line represents the mean monthly air temperature

For each of the examined aforementioned seven stations the thermal human-bioclimate conditions, described through mean conditions, extremes and frequencies of thermal perception classes were analysed. Fig. 2 shows the bioclimate diagram for Heraklion for the period $1955-2001$. The thermal human-bioclimate conditions are expressed in percentages of the occurrence of classes for ten day intervals (dekas). Results presented in Fig. 2 show that $50 \%$ of the days from the $11^{\text {th }}$ dekas to the $30^{\text {th }}$ dekas are in the PET-classes of $18^{\circ} \mathrm{C}$ and above. It has to be mentioned that the results of Fig. 2 are based on daily mean values for the meteorological variables. From the $13^{\text {th }}$ to $27^{\text {th }}$ dekas also extreme thermal stress can also be observed for the investigated region. 


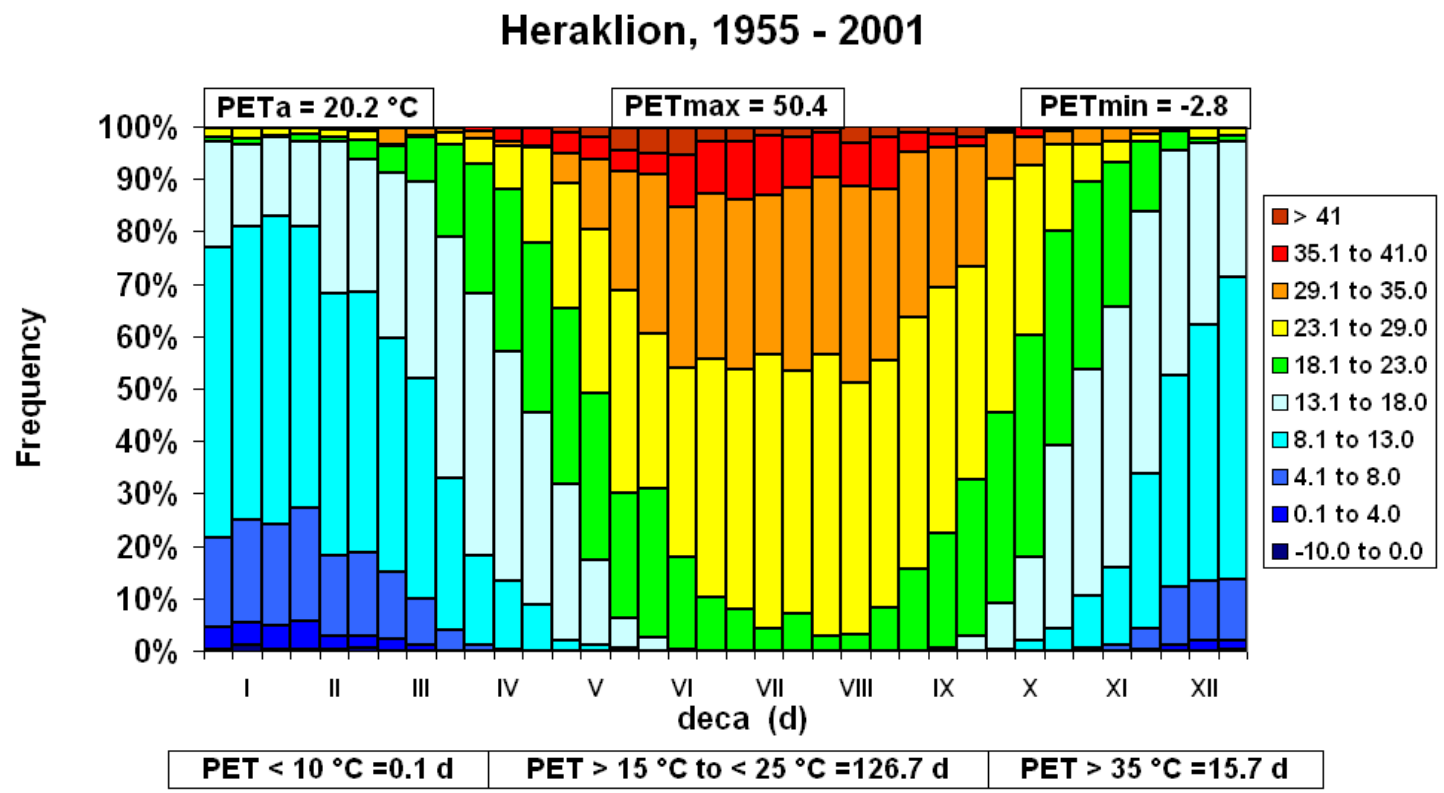

Figure 2. Bioclimate diagram for Heraklion, Crete during the period of time $1955-2001$.

Additionally, the mean PET, the absolute maximum and minimum value and also the frequencies of cold days (days with PET $<10^{\circ} \mathrm{C}$ ), thermal comfort and slight stress days (days with PET between 15 and $25^{\circ} \mathrm{C}$ ) and days with heat stress (days with PET $>35^{\circ} \mathrm{C}$ ) are presented in Fig. 2. Fig. 3 shows the seasonal, annual, and tourism period values of PET for the period of time $1955-2001$ in Heraklion.

\section{Heraklion, 1955 - 2001}

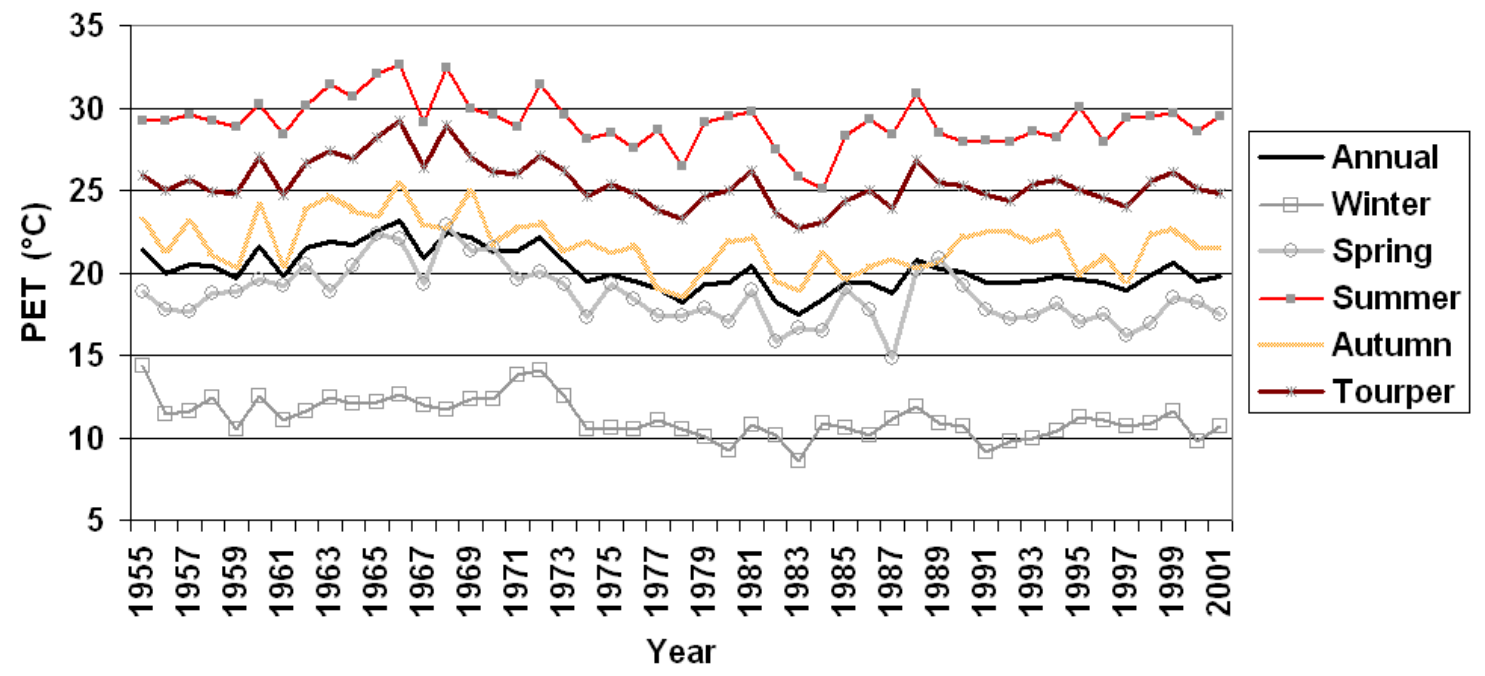

Figure 3. Seasonal, annual and tourism period development of PET $\left({ }^{\circ} \mathrm{C}\right)$ for Heraklion, Crete during the period of time $1955-2001$.

The warm and dry period from April to September is characterised by almost no precipitation and slightly hot air temperatures. The warmest months of this period are July and August. The mean maximum air temperature in these two months varies between 28 and $32{ }^{\circ} \mathrm{C}$, sometimes reaches 34 
- $36{ }^{\circ} \mathrm{C}$ and scarcely, mainly in southern Crete, approaches $40{ }^{\circ} \mathrm{C}$, particularly in plain mainland areas. These high air temperatures in the southern part of Crete are associated with low air humidity and, thus, the thermal comfort conditions in these areas are still tolerable. June shows about the same temperature regime as September, with the later to be considered as a summer month in Crete.

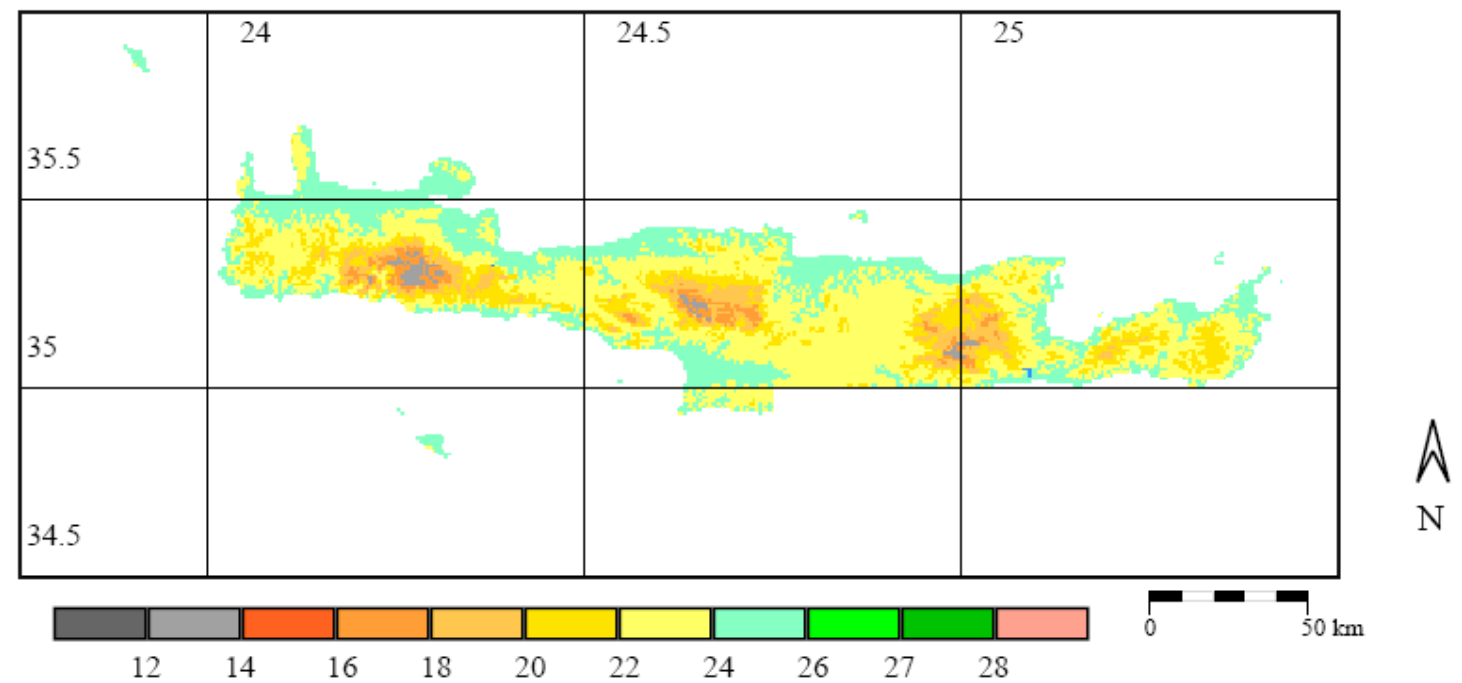

Figure 4. Map of air temperature $\left({ }^{\circ} \mathrm{C}\right)$ for Crete for summer (June, July and August) during the normal period 1961 - 1990 (resolution: $1 \mathrm{~km}$ ).

The precipitation increases from East to West and from the northern coastal areas and southern parts to the inland regions and the highlands. In the mountainous areas of Crete, maximum annual precipitation levels of $1100-1200 \mathrm{~mm}$ are observed. Even higher levels $(1600 \mathrm{~mm})$ are observed in the Lefka Ori mountain range (western part). The lowest annual precipitation levels of about $500 \mathrm{~mm}$ or less are recorded in the southern parts of Heraklion Prefecture (central part), particularly in the Mesara plain and Viannos area. Snow only falls in the mountains, mainly in the Lefka Ori Mountain range (west part) and the Psiloriti Mountain range (central part), while in the lowlands and coastal areas snowfall is a sporadic phenomenon.

Fig. 4 shows the distribution of air temperature for summer (June, July, August) in a spatial resolution of $1 \mathrm{~km} \times 1 \mathrm{~km}$, which represents the spatial variation of air temperature conditions for the whole island fairly well. Except for the air temperature as a common climatic parameter, in terms of precipitation, it is not only important to consider the precipitation sum for the whole year, but also the sum of precipitation during the tourism period as well is analysed.

An analysis of the number of days with rain $(>1 \mathrm{~mm}$ ) provides more useful information for the tourism period. Fig. 5 shows the number of days with precipitation for the tourism period in Crete (April to October) for the normal period 1961 -1990. Fig. 5 demonstrates that the number of days with precipitation is generally low, with less than 15 days for the areas of low altitude.

Fig. 6 shows the sum of precipitation for the tourism period (April to October) for the normal period 1961 - 1990. The same figure also shows that precipitation is less than $180 \mathrm{~mm}$ for the low lying areas and increases in highland areas, exceeding $300 \mathrm{~mm}$ from April to October. In addition, Fig. 7 illustrates the sum of precipitation in $\mathrm{mm}$ and the amount of days with precipitation $(>1 \mathrm{~mm})$ in Heraklion for April to October for the period of time 1955 to 2001.

As mentioned above, results derived from thermal human-bioclimate data can provide more detailed information about the bioclimatic conditions of an area. The high spatial resolution based on existing and free available elevation data (Hastings et al., 1999) built a good opportunity for climate and bioclimate studies. The produced and existing data sets include not only information about air temperature, but also additional meteorological variables (air humidity, wind speed and sunshine duration. From these data information of short- and long wave radiation fluxes and thermal indices can be calculated by RayMan model (Matzarakis et al., 2010). The thermal bioclimate regime of an area can be quantified by the use of thermal indices (i.e. PET). Fig. 8 shows the geographical distribution of the Physiologically Equivalent Temperature for summer (June, July, August) for the 
normal period 1961 - 1990. When compared with the map of air temperature from Fig. 4, we can assume that thermal comfort cannot be described by one single meteorological parameter, such as air temperature.

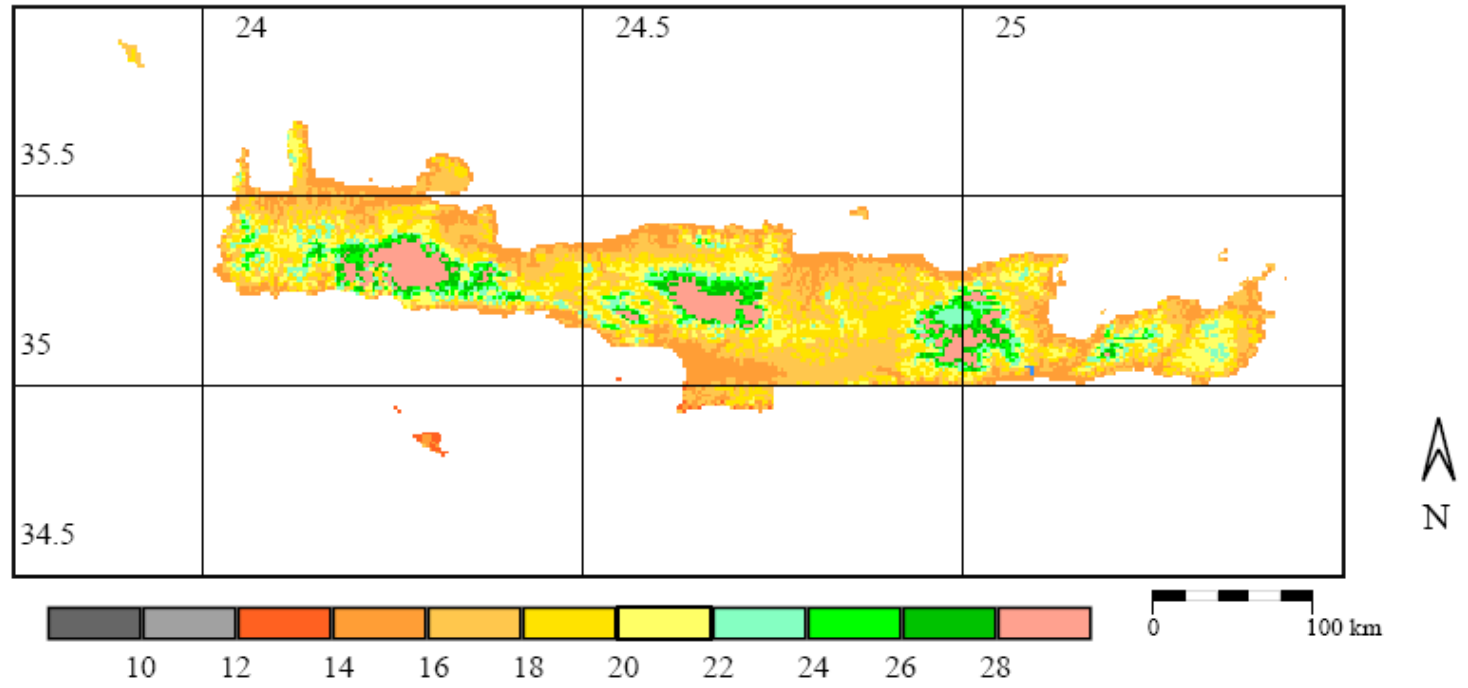

Figure 5. Map of number of days with precipitation (>1 mm) for the tourism period (April to October), during the normal period $1961-1990$ (resolution: $1 \mathrm{~km}$ ).

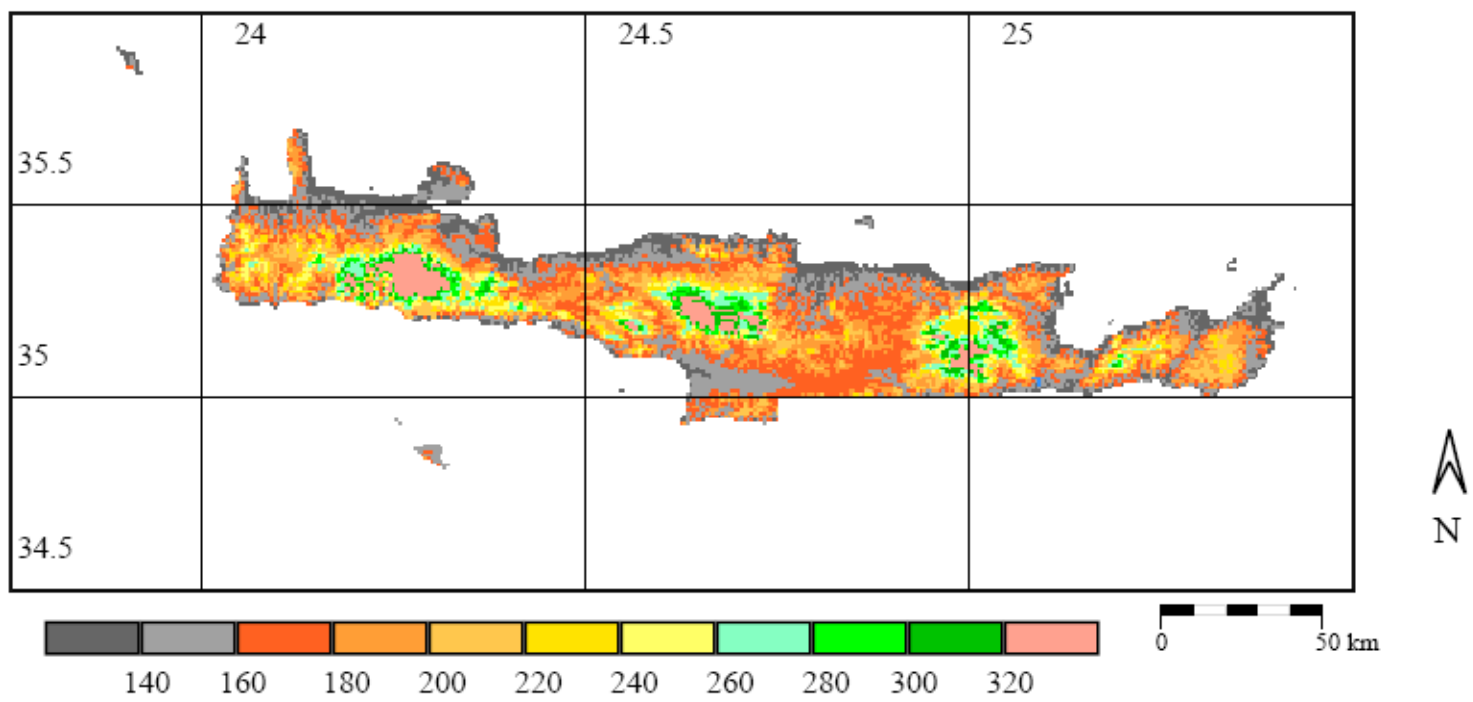

Figure 6. Map of total precipitation $(\mathrm{mm})$ for the tourism period (April to October) during the normal period 1961 - 1990 (resolution: $1 \mathrm{~km}$ ). 


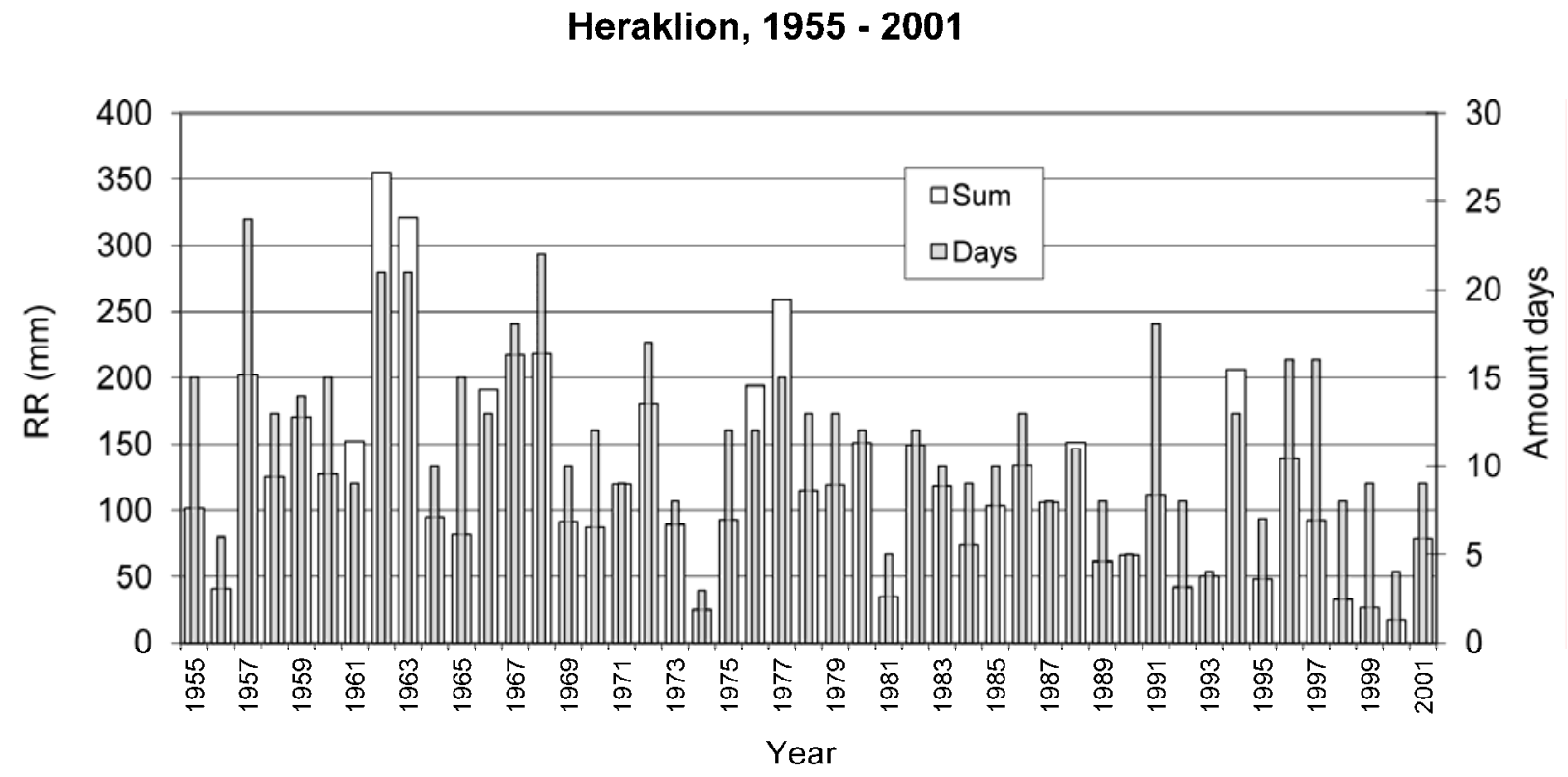

Figure 7. Precipitation totals ( $\mathrm{mm}$ ) and amount of days with precipitation (> $1 \mathrm{~mm}$ ) in Heraklion during the period 1955 to 2001.

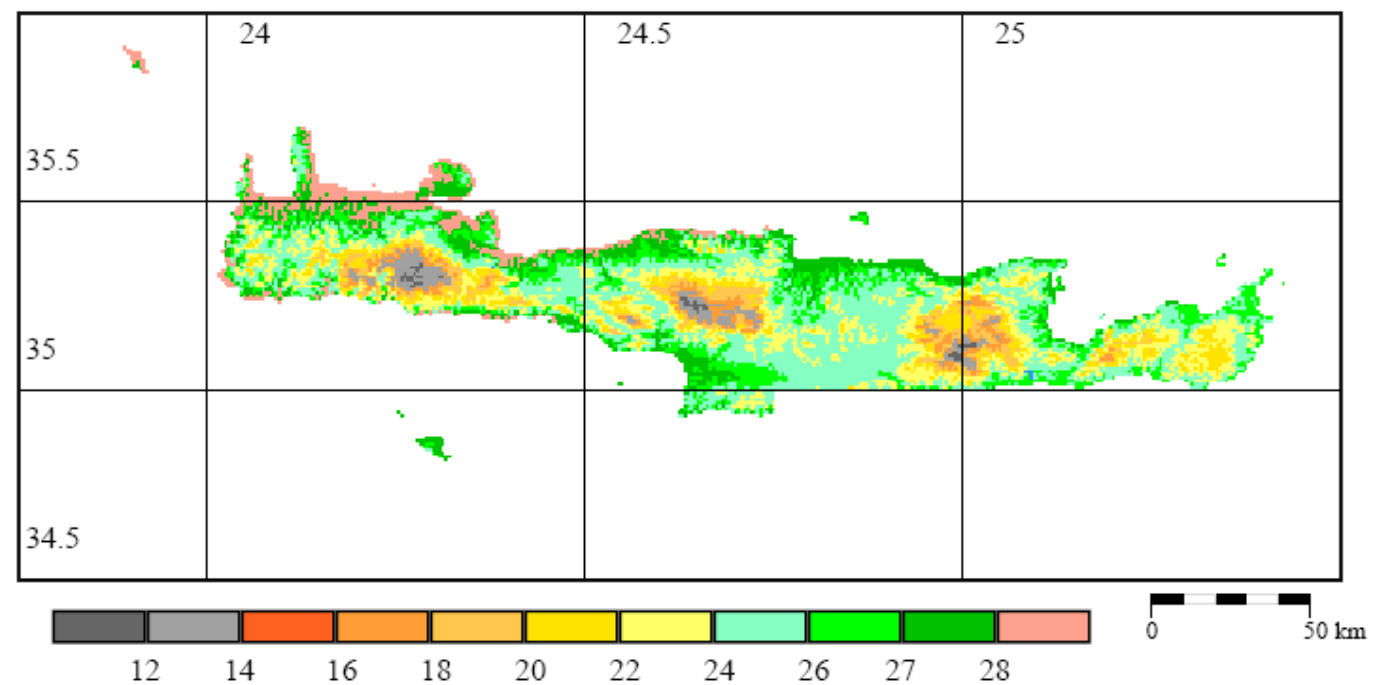

Figure 8. Map of Physiologically Equivalent Temperature $\left({ }^{\circ} \mathrm{C}\right)$ for Crete for Summer (June, July, August) during the normal period $1961-1990$ (resolution: 1 km).

\section{CONCLUSIONS}

For the identification and quantification of the tourism climate and tourism potential, manifold climatic and bioclimatic information can be provided by applied climatology and human biometeorology. The existing information and provided material have to be reliable and accessible. Information can be provided in traditional ways of presentations like ombro-thermal diagrams. The existing climatic networks, beside the synoptical networks from national weather services, offer suitable data for the regionalisation of climate information through the application of geo-statistical methods. The existing data sets also provide an opportunity for the calculation of thermal indices in order to access and quantify the climate in human-biometeorological terms. Data from the climate networks also allow the calculation of frequencies and extremes, i.e. the amount of days with precipitation for the tourism period or the detection of frequencies of heat waves.

Human-biometeorological methods can be applied for tourism climatology and tourism potential issues. Analysis of single climatic variables and thermal indices in form of means, extremes and frequencies do not present an integral assessment of the tourism potential of a region. Integral assessment should cover diverse aspects of the climate and physical environment (Matzarakis et al., 
2004; Koch et al., 2005). UV-Information, sunshine duration and possible extreme events or damages for health should be considered in the analysis of tourism climate. The produced maps show that the use of geo-statistical methods and the implementation of data sets from climate models represent opportunities for results with a high spatial resolution.

The analysis for Crete shows that the natural tourism potential is high and, thus, an extension of the tourism period is possible. The mild periods of the year are suitable for wellness and cultural tourism of specific population groups and, therefore, contribute to the extension of Crete's tourism period.

The next step will be an integral assessment of the climate and bioclimate conditions, including UV and sunshine duration information and extreme events, in order to describe the conditions in the format demanded by the tourism industry and stake holders.

ACKNOWLEDGEMENT: Authors thank the Hellenic National Meteorological Service for providing the climatic data.

\section{REFERENCES}

Amelung B., Nicholls S. and Viner D. (2007), Implications of Global Climate Change for Tourism Flows and Seasonality, Journal of Travel Research, 45, 285-296.

De Freitas C.R. (2003), Tourism climatology: evaluating environmental information for decision making and business planning in the recreation and tourism sector, International Journal of Biometeorology, 4, 45-54.

Didaskalou E. and Nastos P. (2003), The Role of Climatic and Bioclimatic Conditions in the Development of Health Tourism Product, Anatolia, 14 (2),107-126.

Didaskalou E., Nastos P. and Matzarakis A. (2004), The Development Prospects of Greek Health Tourism and the Role of the Bioclimate Regime of Greece. In Matzarakis, A. de Freitas, C.R and Scott D. (Eds), Advances in Tourism Climatology, Ber. Meteorol. Inst. Univ. Freiburg Nr. 12, pp. 149157.

Didaskalou E., Nastos P. and Matzarakis A. (2007), Spa destination development using decision support system. The role of climate and bioclimate information. In Matzarakis, A., de Freitas, C.R and Scott, D. (Eds), Developments in Tourism Climatology, pp. 158-165.

García-Altés A. (2005), The Development of Health Tourism Services, Annals of Tourism Research, 1, 266-268.

Hamilton J.M. and Lau M.A. (2005), The role of climate information in tourist destination choice decisionmaking. In: Proceedings of the 17th International Congress of Biometeorology (ICB 2005), GarmischPartenkirchen, Germany, 9-5 September 2005. Deutscher Wetterdienst, Offenbach am Main, pp 608611.

Hastings D.A., Dunbar P.K., Elphingstone G.M., Bootz M., Murakami H., Maruyama H., Masaharu H., Holland P., Payne J., Bryant N.A., Logan T., Muller J.-P., Schreier G. and MacDonald J.S. (1999), The Global Land One-kilometer Base Elevation (GLOBE) Digital Elevation Model, Version 1.0. National Oceanic and Atmospheric Administration, National Geophysical Data Center, 325 Broadway, Boulder, Colorado 80303, U.S.A. Digital data base on the World Wide Web (URL: http://www.ngdc.noaa.gov/mgg/topo/globe.html). June 2009.

Höppe P. (1999), The Physiologically equivalent temperature in a universal index for the biometeorological assessment of the thermal environment. International Journal of Biometeorology, 43, 71-75.

Koch E., Marktl W., Matzarakis A., Nefzger H., Rudel E., Schunder-Tatzber S. and Zygmuntowski M. (2005), Klimatherapie in Österreich. Broschüre zu den Potentialen der Klimatherapie in Österreich. Bundesministerium für Wirtschaft und Arbeit.

Lin T.P., Hwang C.C. and Cheng H.Y. (2006), The Influence of Climate Information on Travel Arrangements. In: Proceedings of the 8th Leisure, Recreation and Tourism Research Symposium, Taipei, 7 October 2006. Outdoor Recreation Association, Taipei, pp 120-126.

Matzarakis A., Mayer H. and Iziomon M.G. (1999), Applications of a universal thermal index: Physiologically equivalent temperature, International Journal of Biometeorology, 43, 76-84.

Matzarakis A., de Freitas C. and Scott D. 2004 (eds.), Advances in tourism climatology. Ber. Meteorol. Inst. Univ. Freiburg Nr. 12.

Matzarakis A., Rutz F. and Mayer H. (2010), Modelling Radiation fluxes in simple and complex environments - Basics of the RayMan model, International Journal of Biometeorology, 54,131-139.

Meteorological Office (1962), Weather in the Mediterranean, Vol. 1, $2^{\text {nd }}$ ed., HMSO. 
New M., Hulme M. and Jones P.D. (2000), Representing twentieth century space-time climate variability. Part 2: development of 1901-96 monthly grids of terrestrial surface climate, Journal of Climate, 13, 2217-2238.

New M., Hulme M. and Jones P. (1999), Representing twentieth century space-time climate variability. Part 1: development of a 1961-1990 mean monthly terrestrial climatology, Journal of Climate, 12, 829-856.

VDI (1998), Methods for the human-biometerological assessment of climate and air hygiene for urban and regional planning. Part I: Climate, VDI guideline 3787. Part 2. Beuth, Berlin. 